\title{
HOW DOES INVENTORY MANAGEMENT AFFECT ANALYST FORECAST ACCURACY?
}

\author{
DOI: 10.17261/Pressacademia.2019.1012 \\ JBEF- V.8-ISS.1-2019(2)-p.17-27 \\ Chen-Miao Lin ${ }^{1}$, Bingxuan Lin², Henry Schwarzbach ${ }^{3}$ \\ ${ }^{1}$ Clayton State University, Morrow, GA, USA. \\ chen-miaolin@clayton.edu ORCID: 0000-0002-4525-4405 \\ 2 University of Rhode Island, Kingston, Rhode Island, USA. \\ bingxuan@uri.edu \\ ${ }^{3}$ University of Rhode Island, Kingston, Rhode Island, USA. \\ henry@uri.edu
}

Date Received: January 10, 2019

Date Accepted: March 15, 2019

\section{To cite this document}

Lin, C., Lin, B., Schwarzbach, H. (2019). How does inventory management affect analyst forecast accuracy? Journal of Business, Economics and Finance (JBEF), V.8(1), p.17-27.

Permemant link to this document: http://doi.org/10.17261/Pressacademia.2019.1012

Copyright: Published by PressAcademia and limited licenced re-use rights only.

\section{ABSTRACT}

Purpose - This paper aims to examine the association between inventory level and analyst forecast accuracy. Firms can potentially manage earnings through inventory manipulation, and we hypothesize that it is therefore more difficult to forecast earnings in companies with large inventories.

Methodology - Analyst forecast accuracy is measured by forecast error, computed as the absolute value of the difference between forecasted earnings per share and actual earnings per share, normalized by the firm's stock price. Univariate tests and regression models are used to examine the relation between forecast error and inventory level. We further investigate whether analyst experience and the level of institutional ownership can reduce the forecast error.

Findings - The results show that forecast error is greater in firms with relatively higher levels of inventories and the size of the error decreases as analyst experience and the level of institutional ownership increase.

Conclusion - This study demonstrates that it is important for analysts to take extra care in forecasting earnings for companies with a history of high inventory levels.

Keywords: Earnings management, inventories, forecast accuracy, institutional investors, analyst experience.

JEL Codes: G17, G30, M41

\section{INTRODUCTION}

Literature has documented that firms have incentives to engage in earnings management. The incentives include: enjoy a higher stock return (Bartov et al., 2002), avoid a decline in managerial compensation and career turnover rate (Guidry et al., 1999; Healy, 1985; Matsunaga and Park, 2001; Bergstresser and Philippon, 2006; Hazarika et al., 2012; Mergenthaler et al., 2012), affect the offering prices of the stocks prior to initial public offerings (Teoh, et al., 1998a), seasoned equity offerings (Rangan, 1998; Teoh et al., 1998b; Shivakumar, 2000; DuCharme et al., 2004; Cohen and Zarowin, 2010), and management buyout offerings (DeAngelo, 1986; Perry and Williams, 1994; Chou et al., 2006), reduce political costs (Key, 1997; Watts and Zimmerman, 1986), signal manager's private information (Healy and Papepu, 1995), and avoid debt covenant violations (DeFond and Jiambalvo, 1994). 
Firms can mask their true performance by manipulating accruals or employing real activities. This paper focuses on potential inventory manipulation and empirically examines the impact of the relative size of inventories on forecast accuracy. Roychowdhury (2006) finds that when earnings are close to zero, management often engages in overproduction, which results in lower fixed cost per unit and accordingly lower cost of goods sold, higher inventories, and higher profit. Bruggen et al. (2011) also find that companies with high fixed manufacturing overhead tend to overproduce if managers believe earnings will fall short of the levels of income needed for executive bonuses.

Though if a firm overproduces, it will have higher inventory level. However, declining sales can also cause excess inventories. The determination of inventory values and cost of sales for a manufacturing company can be complex especially if there is a high level of fixed overhead. High inventories can also be a consequence of poor forecasts of demand by management, or subpar operational performance, resulting in less sales and higher inventories. High inventory level may also signal that a company is uncertain of sales and thus maintains a large safety stock consistent with the "stock out model" (see Kahn, 1987; Bernard and Noel, 1991). Prior studies report that complexity decreases forecast accuracy (Plumlee, 2003; Gu and Wang, 2005). For these reasons, it should be more difficult to forecast earnings for companies with higher levels of inventories and thus one would expect larger forecast errors or less forecast accuracy if analysts do not fully incorporate the potential earnings management via large inventories into the forecasting models.

We find that there is a positive relationship between a firm's inventory level and forecast error. We further investigate whether analyst experience can reduce the forecast error. Prior studies find that experienced analysts make more accurate forecasts because their analytic skills, relationship with the managers, or understanding of the companies and industries improve over time through experience (Mikhail et al., 1997; 2003; Clement, 1999). Along this line, we find that forecast error associated with inventories is negatively related to analyst experience. We also find that forecast errors are reduced for high institutional ownership firms.

The remainder of the paper proceeds as follows: Section 2 reviews the literature, Section 3 presents data and Section 4 describes our methods. Section 5 reports the findings of our univariate and multivariate analysis while Section 6 gives the concluding remarks.

\section{LITERATURE REVIEW}

Firms can engage in earnings management activities by manipulating accruals or employing real activities. Accruals manipulation is generally achieved by the flexibility of accounting choices. Managers alter financial reports via accounting estimates and methods to mislead stakeholders of firm performance. For example, managers can change the depreciation method for fixed assets and/or LIFO/FIFO method for cost of goods sold. There is plenty of direct evidence that firms engage in accruals manipulation (see Schipper, 1989; Healy and Wahlen, 1999; Fields et al., 2001 for a comprehensive review of this literature).

Roychowdhury (2006) defines real activities management as "departures from normal operational practices, motivated by managers' desire to mislead at least some stakeholders into believing certain financial reporting goals have been met in the normal course of operations." Real management activities are employed by altering the timing of transactions and investment, boosting sales by price discounts, reducing R\&D and advertising expenses, lowering the cost of goods sold per unit by overproduction, etc.

Prior studies have documented empirical evidence on real activities manipulation. For example, Dechow and Sloan (1991), Baber et al. (1991) and Bushee (1998) find that managers reduce R\&D expenditures to meet or beat earnings targets. Thomas and Zhang (2002) and Jiambalvo et al. (1997) report evidence that firms overproduce to manipulate income. Empirical studies also document that firms engage in real activities manipulation through a reduction in advertising expenditures (Cohen et al., 2010), asset sales (Herrmann et al. 2003; Bartov, 1993), sales price reductions (Jackson and Wilcox 2000), and stock repurchases (Hribar et al., 2006).

The main difference between accrual-based and real earnings strategies is that real management activities have a direct influence on a firm's operating activities and cash flows while accrual-based manipulation does not. Real activities manipulation can therefore potentially reduce firm value because actions taken to boost short-term earnings by changing a firm's operating activities and cash flows can have a negative impact on a firm's long-term performance (Bushee, 1998; Roychowdhury, 2006). For example, reducing R\&D and advertising expenses can reduce sales volumes in future periods. Conversely, accrual manipulation is less likely to have a negative impact on firm value since it involves only changes to the accounting methods, if such changes are within the limits of generally accepted accounting principles (Cohen and Zarowin, 2010; Zang, 2012). 
Cohen et al. (2008) document that the level of accrual-based earnings management declines while the level of real activities manipulation increases after the passage of Sarbanes-Oxley Act (SOX) in 2002. Their results suggest the importance of scrutiny of accounting practice on accruals management. However, empirical findings presented in Dechow et al. (1996) report evidence that real activities are more difficult to be detected by regulators, auditors, and financial analysts than accruals manipulation. Along this line, a survey conducted by Graham et al. (2005) find that most companies prefer to use real activities to manipulate earnings.

A large body of literature has noted a positive impact of corporate governance on earnings management activities. For example, several studies find board independence can reduce the extent of earnings management (see for example, Klein, 2002; Xie et al., 2003). Other corporate governance mechanisms that can mitigate earnings management include audit committees (Bedard et al., 2004; Agrawal and Chadha, 2005), institutional shareholders (Chung et al., 2002; Hadani et al., 2011), and large shareholdings of managers and block-holders (Warfield et al., 1995; Dechow et al., 1996).

\section{DATA AND METHODOLOGY}

\subsection{Data Description}

We collect analysts' earnings forecasts from IBES over the years between 2001 and 2012. To enter into the sample, we require at least one earnings forecast made by individual analyst during the three months after the announcement of prior-year's earnings. We focus on this three-month window to examine analysts' responses to freshly released market risk. The institutional ownership data are from the $13 \mathrm{~F}$ database of Thomson Reuters. We obtain financial data from Compustat database.

\subsection{Methodology}

\subsubsection{Computing Analyst Forecast Error}

We compute analyst forecast error to measure analyst forecast accuracy. Small forecast errors represent a high level of accuracy. In each calendar year $t$, we identify a firm's earnings announcement date for fiscal year $t$. We then obtain individual analyst's earnings forecasts for the coming fiscal year $t+1$ from the IBES, made within three months after the announcement date of fiscal year $t$. If during the three months there are multiple forecasts made by analyst $i$ on firm $j$, we only keep the latest one. We calculate the forecast error (FE) by analyst $i$ on firm $j$ for fiscal year $t+1$ as the absolute value of the earnings forecast error, normalized by firm $j$ 's stock price at the end of year $t$ as follows:

$$
F E_{j, i, t+1}=\left|\frac{E P S_{F O R_{j, i, t+1}}-\text { EPS }_{A C T_{j, i, t+1}}}{\text { StockPrice }_{j, t}}\right|
$$

In equation (1), EPS $S_{F O R}$ is the forecasted earnings per share and PPS $_{\mathrm{ACT}}$ is the actual earnings per share.

\subsubsection{Multivariate Framework}

Following Clement and Tse (2003) we specify the relation between FE and inventories as follows:

$F E_{j, i, t+1}=f$ (Inventories $_{j, i, t}$, Frequency ${ }_{j, i, t,}$ Companies $_{j, i, t,}$ Experience $_{j, i, t,}$ Institutional Ownership $p_{j, i, t,}$ Market-to-Book $_{j, i, t,}$ Size $_{j, i, t,}$ Accruals $_{j, i, t,}$ Year Dummies)

Inventories are measured as inventories over sales. Frequency is the number of earnings forecasts on the firm $j$ provided by the analyst $i$ for year $t$. Companies are defined as the number of companies analyst $i$ follows for year $t$. Experience is the number of years prior to the time of measuring forecast error, for which analyst $i$ has issued earnings forecasts for firm $j$. We expect a negative relation between FE and frequency, companies and experience (see Mikhail et al., 1997; 2003; Clement, 1999). Institutional ownership, used as a proxy for analyst incentive, is computed as the percentage of shares outstanding owned by institutional investors. Ljungqvist et al. (2007) argue a demand-side disciplinary effect; that is, with the presence of institutional investors, analysts are less likely to succumb to investment banks since institutional investors demand for accurate and unbiased equity research.

Market-to-Book is measured as the ratio of market value of equity to the book value of equity. Literature documents that low market-to-book firms are more difficult to forecast (see for example Siegel et al., 2011). Size is measured as the natural logarithm of total assets and is expected to be negatively related to FE since larger firms have less information uncertainty. Accruals are the total current accruals computed by using modified Jones (1991) model and are expected to be negatively associated with FE (see Kasznik, 1999). We also include year dummy variables to control for the possible time effects on FE. 
Table 1 presents summary statistics for all variables used in our study. The mean (median) of forecast error is around 3.68\% (0.73\%). Inventory level is on average about $9.92 \%$ of total sales with a median of $5.99 \%$. The mean (median) of forecast frequency is 21 (18) and the mean (median) number of companies covered by an analyst is 20 (19).

Table 1: Summary Statistics of Variables

Panel A: Analyst Characteristics

\begin{tabular}{lllll}
\hline Variable & $\mathrm{N}$ & Mean & Median & Standard Deviation \\
\hline Forecast error & 273,193 & 0.03684 & 0.00726 & 0.11676 \\
Frequency & 247,295 & 20.87341 & 18.00000 & 15.79845 \\
Companies & 273,193 & 20.24300 & 19.00000 & 11.08630 \\
Experience & 273,193 & 3.14826 & 2.00000 & 2.99334 \\
\hline
\end{tabular}

Panel B: Firm Characteristics

\begin{tabular}{lllll}
\hline Variable & $\mathbf{N}$ & Mean & Median & Standard Deviation \\
\hline Inventories & 32,309 & 0.09921 & 0.05994 & 0.13710 \\
Institutional ownership & 39,394 & 0.58096 & 0.61270 & 0.30555 \\
Market-to-Book & 28,302 & 2.12338 & 1.53167 & 2.00953 \\
Total assets (millions) & 33,386 & $11,356.07$ & 868.86 & $83,114.76$ \\
Accruals & 26,872 & -0.04267 & -0.04053 & 0.12968 \\
\hline
\end{tabular}

\section{FINDINGS AND DISCUSSIONS}

\subsection{Univariate Results}

To conduct the univariate test, we first sort all firms with their levels of inventories. The bottom decile (10) includes firms with the highest level of inventories in our sample. We then average all FE for each decile and calculate the difference in mean values of FE between deciles 1 and 10. Table 2 provides the results. We find an overall increase in FE with inventory level. Firms with the lowest level of inventories have an average FE of 0.0386 or $3.86 \%$ compare to $5.838 \%$ for firms with the highest level of inventories. The difference in FE between deciles 1 and 10 is $1.978 \%$ and is significant at $1 \%$ level.

\section{Table 2: Forecast Error and Inventories}

\begin{tabular}{ll}
\hline Grouped by inventories & Mean Forecast Error \\
\hline 1 (smallest) & 0.03860 \\
2 & 0.02906 \\
3 & 0.02947 \\
4 & 0.03186 \\
5 & 0.02913 \\
6 & 0.02894 \\
7 & 0.02818 \\
8 & 0.02616 \\
9 & 0.03792 \\
10 (highest) & 0.05838 \\
\hline Portfolio 10 - Portfolio 1 & $0.01978^{* * *}$ \\
\hline
\end{tabular}

$* * *, * *, *$ denote statistical significance at the 1,5 , and 10 percent levels, respectively. 
We next investigate if analyst experience can reduce FE associated with the inventory level. A more experienced analyst may better understand a firm's earning management strategy and therefore make a more accurate forecast. In each year $t$, we sort firms into 10 portfolios based on their levels of inventories and then within each portfolio we sort FE into four quartiles based on analyst experience. We calculate the mean values of FE for each portfolio and the difference in mean values of FE for the portfolios with the most (Q4) and least (Q1) experienced analysts.

Table 3 reports our results. Within each analyst experience quartile, we find that the higher the inventory level is, the larger the forecast error. For example, for the most experienced analyst quartile (Q4), the mean value of FE is $3.167 \%$ for the lowest level of inventories and is $5.571 \%$ for the highest level of inventories. The difference is $2.404 \%$ and is significant at $1 \%$ level. We further find that FE decreases as analyst experience increases. For the portfolio with the lowest level of inventories, the average value of $\mathrm{FE}$ for the least experienced analysts is $4.07 \%$ and $3.167 \%$ for the most experienced analysts, which represents a significant ( $1 \%$ level) difference of $0.902 \%$. The reduction in FE associated with analyst experience is significant for all levels of inventories except for the highest level of inventories.

Table 3: Forecast Error, Inventories and Analyst Experience

\begin{tabular}{|c|c|c|c|c|c|c|}
\hline \multirow[b]{2}{*}{ Grouped by Inventories } & \multicolumn{6}{|c|}{ Analyst Experience Quartiles } \\
\hline & Q1 (Low) & Q2 & Q3 & Q4 (High) & High - Low & t-stat \\
\hline 1 (smallest) & 0.04070 & 0.04098 & 0.03795 & 0.03167 & $-0.00902 * * *$ & 5.84 \\
\hline 2 & 0.03160 & 0.03417 & 0.03192 & 0.01679 & $-0.01481 * * *$ & 4.89 \\
\hline 3 & 0.03280 & 0.03155 & 0.03002 & 0.02242 & $-0.01038 * * *$ & 5.7 \\
\hline 4 & 0.03356 & 0.03365 & 0.03023 & 0.02956 & $-0.00399 *$ & 1.91 \\
\hline 5 & 0.03153 & 0.03037 & 0.02851 & 0.02585 & $-0.00567 * * *$ & 2.98 \\
\hline 6 & 0.03067 & 0.03065 & 0.03247 & 0.02309 & $-0.00758 * * *$ & 4.22 \\
\hline 7 & 0.03327 & 0.02909 & 0.02851 & 0.02197 & $-0.01131 * * *$ & 5.93 \\
\hline 8 & 0.02920 & 0.03322 & 0.02336 & 0.02049 & $-0.00871^{* * *}$ & 5.42 \\
\hline 9 & 0.04060 & 0.04339 & 0.03387 & 0.03411 & $-0.00649 * * *$ & 2.94 \\
\hline 10 & 0.05560 & 0.06211 & 0.06260 & 0.05571 & 0.00011 & -0.04 \\
\hline Group 10 - Group 1 & $0.01490 * * *$ & $0.02112 * * *$ & $0.02465 * * *$ & $0.02404 * * *$ & & \\
\hline t-stat & 7.23 & 6.75 & 8.34 & 8.80 & & \\
\hline
\end{tabular}

$* * *, * *, *$ denote statistical significance at the 1,5 , and 10 percent levels, respectively.

We then examine how institutional ownership affects the relation between FE and inventories. Our hypothesis is that the positive impact of inventory level on FE can be mitigated by the demands from institutional investors for accurate and unbiased equity research. Follow the same procedure we do earlier, in each year $t$, we sort firms into 10 portfolios based on their levels of inventories and then within each portfolio we sort FE into four quartiles based on the levels of institution ownership and finally calculate the mean value of FE for each portfolio.

We present the results in Table 4 Panel A. We find that within each institutional ownership quartile, there is a positive association between FE and inventory level. For example, for the highest rank of institutional ownership (Q4), we find that the mean value of FE for the lowest level of inventories is $2.241 \%$ and is $3.783 \%$ for the highest level of inventories, which represents a significant ( $1 \%$ level) difference of $1.542 \%$. We further find that FE tends to decrease as the level of institutional ownership increases. The reduction in FE associated with institutional ownership is significant at $1 \%$ level for all levels of inventories. The most significant differences in mean values of FE are for the two highest levels of inventories (groups 9 and 10). For group 9, the mean value of FE for the lowest rank of institutional ownership (Q1) is $9.464 \%$ and is $1.873 \%$ for the highest rank of institutional ownership (Q4). The difference is $7.591 \%$ and is significant at $1 \%$ level.

We further investigate the relation between institutional ownership, analyst experience, inventories, and FE. We first sort firms into five portfolios based on their levels of inventories. Within each portfolio, we then sort firms into 3 terciles based on their levels of institutional ownership and we finally sort FE into quartiles based on analyst experience. 
Table 4 Panel B, C, D report the relation between inventories, FE, and analyst experience for the low, median, and high institutional ownership tercile, respectively. Again, we find that across analysts with similar experience, there is a positive relation between FE and inventory level. For example, in Panel B, for the most experienced analysts (Q4), the mean value of FE is $5.75 \%$ for the lowest level of inventories and is $9.14 \%$ for the highest level of inventories. The difference is $3.39 \%$ and is significant at $1 \%$ level. Across firms with similar level of inventories, FE generally decreases as analyst experience increases. However, the reduction is the largest in magnitude for inventory group 2 in the high institutional ownership tertile. In particular, the difference in the mean values of FE between analyst experience quartile 4 and 1 is $1.747 \%$ for inventory group 2 in the high institutional ownership tertile while the largest difference in FE for the low institutional ownership tertile is $1.03 \%$ (inventory group 3) and $0.598 \%$ for median institutional ownership tertile (inventory group 4 ).

Table 4: Forecast Error, Inventories, Analyst Experience, and Institutional Ownership

Panel A: Average Forecast Error for Portfolios Sorted by Inventories and Institutional Ownership

\begin{tabular}{|c|c|c|c|c|c|c|}
\hline \multirow[t]{2}{*}{ Grouped by Inventories } & \multicolumn{6}{|c|}{ Institutional Ownership Quartiles } \\
\hline & Q1 (Low) & Q2 & Q3 & Q4 (High) & High - Low & t-stat \\
\hline 1 (smallest) & 0.07350 & 0.02848 & 0.02755 & 0.02241 & $-0.05109 * * *$ & 28.07 \\
\hline 2 & 0.04214 & 0.01994 & 0.02157 & 0.02810 & $-0.01404 * * *$ & 3.24 \\
\hline 3 & 0.04235 & 0.02199 & 0.02296 & 0.02807 & $-0.01428 * * *$ & 6.21 \\
\hline 4 & 0.04497 & 0.03381 & 0.02388 & 0.02206 & $-0.02291 * * *$ & 10.21 \\
\hline 5 & 0.04414 & 0.03298 & 0.02071 & 0.01866 & $-0.02548 * * *$ & 12.09 \\
\hline 6 & 0.05577 & 0.01921 & 0.02066 & 0.02564 & $-0.03012 * * *$ & 10.55 \\
\hline 7 & 0.06194 & 0.02016 & 0.02359 & 0.01610 & $-0.04585 * * *$ & 15.92 \\
\hline 8 & 0.06327 & 0.01922 & 0.01529 & 0.01806 & $-0.04521 * * *$ & 15.46 \\
\hline 9 & 0.09464 & 0.03002 & 0.01991 & 0.01873 & $-0.07591 * * *$ & 21.69 \\
\hline 10 & 0.09236 & 0.05780 & 0.03723 & 0.03783 & $-0.05452 * * *$ & 16.22 \\
\hline Group 10 - Group 1 & $0.01885^{* * *}$ & $0.02932 * * *$ & $0.00968 * * *$ & $0.01542 * * *$ & & \\
\hline t-stat & 5.56 & 11.69 & 4.75 & 8.72 & & \\
\hline
\end{tabular}

$* * *, * *, *$ denote statistical significance at the 1,5 , and 10 percent levels, respectively.

Panel B: Average Forecast Error for Portfolios Sorted by Inventories and Analyst Experience Low Institutional Ownership Tercile

\begin{tabular}{|c|c|c|c|c|c|c|}
\hline & \multicolumn{6}{|c|}{ Analyst Experience Quartiles } \\
\hline & Q1 (Low) & Q2 & Q3 & Q4 (High) & High - Low & t-stat \\
\hline 1 (smallest) & 0.06165 & 0.06420 & 0.07097 & 0.05750 & -0.00415 & 0.87 \\
\hline 2 & 0.03882 & 0.04157 & 0.04375 & 0.03240 & -0.00642 & 1.40 \\
\hline 3 & 0.04665 & 0.04336 & 0.04274 & 0.03635 & $-0.01030 * * *$ & 2.35 \\
\hline 4 & 0.05095 & 0.05214 & 0.05272 & 0.04565 & -0.00531 & 1.22 \\
\hline 5 & 0.06836 & 0.07364 & 0.09202 & 0.09140 & $0.02303 * * *$ & -3.71 \\
\hline Group 5 - Group 1 & 0.00672 & $0.00944 * * *$ & $0.02105 * * *$ & $0.03390 * * *$ & & \\
\hline t-stat & 1.16 & 2.59 & 4.90 & 6.48 & & \\
\hline
\end{tabular}

$* * *, * *, *$ denote statistical significance at the 1,5 , and 10 percent levels, respectively. 
Panel C: Average Forecast Error for Portfolios Sorted by Inventories and Analyst Experience Median Institutional Ownership Tercile

\begin{tabular}{|c|c|c|c|c|c|c|}
\hline & \multicolumn{6}{|c|}{ Analyst Experience Quartiles } \\
\hline & Q1 (Low) & Q2 & Q3 & Q4 (High) & High - Low & t-stat \\
\hline 1 (smallest) & 0.02759 & 0.02490 & 0.02955 & 0.02743 & -0.00016 & 0.07 \\
\hline 2 & 0.02224 & 0.02345 & 0.02722 & 0.02416 & 0.00193 & -0.99 \\
\hline 3 & 0.02382 & 0.02316 & 0.02586 & 0.02043 & $-0.00339 *$ & 1.79 \\
\hline 4 & 0.02136 & 0.02130 & 0.01750 & 0.01538 & $-0.00598 * * *$ & 3.99 \\
\hline 5 & 0.03722 & 0.03763 & 0.03412 & 0.03559 & -0.00163 & 0.65 \\
\hline Group 5 - Group 1 & $0.00963^{* * *}$ & $0.01273 * * *$ & $0.004567^{*}$ & $0.00816 * * *$ & & \\
\hline t-stat & 4.26 & 4.49 & 1.72 & 3.12 & & \\
\hline
\end{tabular}

$* * *, * *, *$ denote statistical significance at the 1,5 , and 10 percent levels, respectively.

Panel D: Average Forecast Error for Portfolios Sorted by Inventories and Analyst Experience High Institutional Ownership Tercile

\begin{tabular}{|c|c|c|c|c|c|c|}
\hline & \multicolumn{6}{|c|}{ Analyst Experience Quartiles } \\
\hline & Q1 (Low) & Q2 & Q3 & Q4 (High) & High - Low & t-stat \\
\hline 1 (smallest) & 0.02092 & 0.02190 & 0.02315 & 0.02369 & $0.00277^{*}$ & -1.82 \\
\hline 2 & 0.03441 & 0.02502 & 0.02643 & 0.01694 & $-0.01747 * * *$ & 6.65 \\
\hline 3 & 0.02110 & 0.02166 & 0.02309 & 0.02194 & 0.00084 & -0.59 \\
\hline 4 & 0.01580 & 0.01957 & 0.01516 & 0.01584 & 0.00004 & -0.04 \\
\hline 5 & 0.02455 & 0.02403 & 0.02728 & 0.02635 & 0.00180 & -1.00 \\
\hline Group 5 - Group 1 & $0.00363 * *$ & 0.00214 & $0.00413^{* *}$ & 0.00266 & & \\
\hline t-stat & 2.52 & 1.10 & 2.13 & 1.42 & & \\
\hline
\end{tabular}

$* * *, * *, *$ denote statistical significance at the 1,5 , and 10 percent levels, respectively.

\subsection{Regression Results}

Table 5 reports the regression results of the estimated relation between FE and inventories. The coefficient on inventories is positive and significant at $1 \%$ level. In particular, the estimated coefficient of 0.0164 on inventories indicates that forecast error increases by $1.64 \%$ for each $1 \%$ increase in the ratio of inventories to total sales. Consistent with prior research, we find that analyst experience is significantly negatively correlated with FE. The negative and significant coefficient on institutional ownership also supports the argument of a demand-side disciplinary effect raised in Ljungqvist et al. (2007). As expected, we find a negative association between FE and market-to-book, size and accruals.

Table 5: Regression of Forecast Error on Inventories

\begin{tabular}{lll}
\hline & coefficient & p-value \\
\hline Intercept & 0.1389 & $<.0001$ \\
Inventories & $0.0164^{* * *}$ & $<.0001$ \\
Log Frequency & $0.0029^{* * *}$ & $<.0001$ \\
Log Companies & -0.0003 & 0.4725
\end{tabular}




$\begin{array}{llr}\text { Log Experience } & -0.0029^{* * *} & <.0001 \\ \text { Institutional ownership } & -0.0536^{* * *} & <.0001 \\ \text { Log Market-to-Book } & -0.0275^{* * *} & <.0001 \\ \text { Size } & -0.0075^{* * *} & <.0001 \\ \text { Accruals } & -0.0467^{* * *} & <.0001 \\ \text { Year Dummies } & \text { Yes } & \\ \text { Number of Observations } & 165,504 & \\ \text { Adj. } \mathrm{R}^{2} & 0.078 & \end{array}$

Next, we further investigate the effect of analyst experience and institutional ownership on the relation between FE and inventories. We first include the interaction term of inventories*experience into the regression model in Table 5. We then test whether the learning effect is stronger when analysts are facing a demand-side disciplinary effect from institutional investors. We sort institutional ownership into three terciles: low, median, and high and include three interaction terms into the previous regression: inventories*experience*low institutional ownership, inventories*experience*median institutional ownership, and inventories*experience*high institutional ownership.

Table 6 Model 1 reports the results when the interaction of inventories and experience is included. Consistent with the findings in Table 5, the coefficient on inventories is still positive and significant at $1 \%$ level. We also find that the coefficient on the interaction of inventories and experience is significantly negative, which indicates that forecast error decreases with forecasting experience.

Table 6 Model 2 reports the results when the interactions of inventories, experience, and institutional ownership are included. Consistent with our hypothesis, we find negative and significant coefficients on inventories*experience*median institutional ownership and inventories*experience*high institutional ownership, but we fail to find the same negative coefficient on inventories*experience*low institutional ownership. Our results suggest that the forecast error associated with inventories is reduced when analysts have more experience and are motivated from institutional investors to deliver timely and accurate forecasts.

Table 6: Regression of Analyst Forecast Error on Inventories, Experience, and Institutional Ownership

\begin{tabular}{|c|c|c|c|c|}
\hline & \multicolumn{2}{|c|}{ Model 1} & \multicolumn{2}{|c|}{ Model 2} \\
\hline & coefficient & p-value & coefficient & p-value \\
\hline Intercept & $0.1384 * * *$ & $<.0001$ & 0.1365 & $<.0001$ \\
\hline Inventories & $0.0229 * * *$ & $<.0001$ & $0.0209 * * *$ & $<.0001$ \\
\hline Inventories $x$ Experience & $-0.0078 * *$ & 0.0144 & & \\
\hline Inventories $x$ Experience $x$ Low Institutional ownership & & & $0.0158 * * *$ & 0.0005 \\
\hline Inventories $x$ Experience $x$ Median Institutional ownership & & & $-0.0195 * * *$ & $<.0001$ \\
\hline Inventories $x$ Experience $x$ High Institutional ownership & & & $-0.0083 * * *$ & 0.0229 \\
\hline Log Frequency & $0.0029 * *$ & $<.0001$ & $0.0029 * * *$ & $<.0001$ \\
\hline Log Companies & -0.0003 & 0.4666 & -0.0003 & 0.4336 \\
\hline Log Experience & $-0.0022 * * *$ & $<.0001$ & $-0.0022 * * *$ & $<.0001$ \\
\hline Institutional ownership & $-0.0535 * * *$ & $<.0001$ & $-0.0513 * * *$ & $<.0001$ \\
\hline Log Market-to-Book & $-0.0275 * * *$ & $<.0001$ & $-0.0274 * * *$ & $<.0001$ \\
\hline Size & $-0.0075^{* * *}$ & $<.0001$ & $-0.0075^{* * *}$ & $<.0001$ \\
\hline Accruals & $-0.0470 * * *$ & $<.0001$ & $-0.0466 * * *$ & $<.0001$ \\
\hline Year Dummies & Yes & & Yes & \\
\hline
\end{tabular}




$\begin{array}{lll}\text { Number of Observations } & 165,504 & 165,504 \\ \text { Adj. } R^{2} & 0.0778 & 0.0782\end{array}$

$* * *, * *, *$ denote statistical significance at the 1,5 , and 10 percent levels, respectively.

\section{CONCLUSION}

Financial analysts have played an important informational role in the financial markets and their forecast accuracy is crucial for investors. Companies' stock prices are often impacted if companies miss or beat the analysts' earnings forecasts (Kasznik, 1999; Athanasakou et al., 2009; Bartov et al., 2002). Our finding shows that firms with higher levels of inventories tend to have larger forecast errors and cautions investors and regulators that inventory level might undermine analysts' informational role.

Further, we find that the forecast error associated with inventories decreases with an increase in analyst experience and the level of institutional ownership. Our findings support the notion that experienced analysts make more accurate forecasts and that the presence of institutional investors motivates analysts to provide accurate and unbiased equity research (Frankel et al., 2006; Ljungqvist et al., 2007; Hong et al., 2000; Hong and Kubik, 2003; and Kothari, 2001).

Our findings overall suggest that when forecast earnings for firms with large inventories, analysts should carefully look at past data for possible inventory manipulation to assess its impact on future earnings. Further research also needs to be conducted to gain an understanding of better forecast models and data collection methods for inventory intensive firms and how to deter earnings management with inventory policy due to the ability of managers to manage earnings through inventory decisions.

\section{REFERENCES}

Agrawal, A., Chadha, S. (2005). Corporate governance and accounting scandals. Journal of Law and Economics, 43(2), 371-406.

Athanasakou, V. E., Strong, N. C., Walker, M. (2009). Earnings management or forecast guidance to meet analyst expectations? Accounting and Business Research, 39(1), 3-35.

Baber, W. R., Fairfield, P. M., Haggard, J. A. (1991). The effect of concern about reported income on discretionary spending decisions: the case of research and development. The Accounting Review, 66(4), 818-829.

Bartov, E. (1993). The timing of asset sales and earnings manipulation. The Accounting Review, 68(4), 840-855.

Bartov, E., Givoly, D., Hayn, C. (2002). The rewards to meeting or beating earnings expectations. Journal of Accounting and Economics, 33(2), 173-204.

Bedard, J., Chtourou, S. M., Courteau, L. (2004). The effect of audit committee expertise, independence, and activity on aggressive earnings management. Auditing: A Journal of Practice and Theory, 23(2), 15-35.

Bergstresser, D., Philippon, T. (2006). CEO incentives and earnings management. Journal of Financial Economics, 80 (3), $511-529$.

Bernard, V., Noel, J. (1991). Do inventory disclosures predict sales and earnings? Journal of Accounting, Auditing, and Finance, 6(2), $145-181$.

Bruggen, A., Krishnan, R., Sedatole, K. L. (2011). Drivers and consequences of short-term production decisions: Evidence for the auto industry. Contemporary Accounting Research, 28(1), 83-123.

Bushee, B. (1998). The influence of institutional investors on myopic R\&D investment behavior. The Accounting Review, 73(3), 305-333.

Chou, D., Gombola, M., Liu, F. (2006). Earnings management and stock performance of reverse leveraged buyouts. Journal of Financial and Quantitative Analysis, 41(2), 407-438.

Chung, R., Firth, M., Kim, J. (2002). Institutional monitoring and opportunistic earnings management. Journal of Corporate Finance, 8(1), 29-48.

Clement, M. (1999). Analyst forecast accuracy: Do ability, resources, and portfolio complexity matter? Journal of Accounting and Economics, 27(3), 285-303.

Clement, M. B., Tse, S. Y. (2003). Do investors respond to analysts' forecast revisions as if forecast accuracy is all that matters? The Accounting Review, 78(1), 227-249.

Cohen, D., Dey, A., Lys, T. (2008). Real and accrual-based earnings management in the pre- and post-Sarbanes-Oxley period. The Accounting Review, 83(3), 757-787. 
Cohen, D., Mashruwala, R., Zach, T. (2010). The use of advertising activities to meet earnings benchmarks: Evidence from monthly data. Review of Accounting Studies, 15(4), 808-832.

Cohen, D. A., Zarowin, P. (2010). Accrual-based and real earnings management activities around seasoned equity offerings. Journal of Accounting and Economics, 50(1), 2-19.

DeAngelo, L. E. (1986). Accounting numbers as market valuation substitutes: A study of management buyouts of public stockholders. The Accounting Review, 61(3), 400-420.

Dechow, P. M., Sloan, R. (1991). Executive incentives and the horizon problem: an empirical investigation. Journal of Accounting and Economics, 14 (1), 51-89.

Dechow, P. M., Sloan, R. G., Sweeney, A. P. (1996). Causes and consequences of earnings manipulation: an analysis of firms subject to enforcement actions by the SEC. Contemporary Accounting Research, 13(1), 1-36.

DeFond, M. L., Jiambalvo, J. (1994). Debt covenant violation and manipulations of accruals. Journal of Accounting and Economics, 17(1-2), 145176.

DuCharme, L. L., Malatesta, P. H., Sefcik, S. E. (2004). Earnings management, stock issues, and shareholder lawsuits. Journal of Financial Economics, 71(1), 27-49.

Fields, T., Lyz, T., Vincent, L. (2001). Empirical research on accounting choice. Journal of Accounting and Economics, 31(1-3): 255-308.

Frankel, R., Kothari, S. P., Weber, J. (2006). Determinants of the informativeness of analyst research. Journal of Accounting and Economics, 41(12), 29-54.

Graham, J. R., Harvey, C. R., Rajgopal, S. (2005). The economic implications of corporate financial reporting. Journal of Accounting and Economics, 40(1-3), 3-73.

Gu, F., Wang, W. (2005). Intangible assets, information complexity, and analysts' earnings forecasts. Journal of Business Finance \& Accounting, 32(9-10), 1673-1702.

Guidry, F., Leone, A. J., Rock, S. (1999). Earnings-based bonus plans and earnings management by business-unit managers. Journal of Accounting and Economics, 26(1-3), 113-142.

Hadani, M., Goranova, M., Khan, R. (2011). Institutional investors, shareholder activism, and earnings management. Journal of Business Research, 64(12), 1352-1360.

Hazarika, S., Karpoff, J. M., Nahata, R. (2012). Internal corporate governance, CEO turnover, and earnings management. Journal of Financial Economics, 104(1), 44-69.

Healy, P. M. (1985). The effect of bonus schemes on accounting decisions. Journal of Accounting and Economics, 7(1-3), 85-107.

Healy, P. M., Palepu, K. (1995). The challenges of investor communication. Journal of Financial Economics, 38(2), 111-140.

Healy, P. M., Wahlen, J. (1999). A review of the earnings management literature and its implications for standard setting. Accounting Horizons, 13(4), 365-383.

Herrmann, D., Inoue, T., Thomas, W. (2003). The sale of assets to manage earnings in Japan. Journal of Accounting Research, 41(1), 89-108.

Hong, H., Kubik, J. D. (2003). Analyzing the analysts: career concerns and biased earnings forecasts. Journal of Finance, 58(1), 313-51.

Hong, H., Kubik, J. D., Solomon, A. (2000). Security analysts' career concerns and the herding of earnings forecasts. Rand Journal of Economics, 31(1), 121-44.

Hribar, P., Jenkins, N., Johnson, W. (2006). Stock repurchases as an earnings management device. Journal of Accounting and Economics, 41(1), $3-27$.

Jackson, S., Wilcox, W. (2000). Do managers grant sales price reductions to avoid losses and declines in earnings and sales? Quarterly Journal of Business and Economics, 39(4), 3-20.

Jiambalvo, J., Noreen, E., Shevlin, T. (1997). Incremental information content of the change in the percent of production added to inventory. Contemporary Accounting Research, 14(1), 69-97.

Jones, J. (1991). Earnings management during import relief investigations. Journal of Accounting Research, 29(2), 193-228.

Kahn, J. (1987). Inventories and volatility of production. The American Economic Review, 77(4), 667-679.

Kasznik, R. (1999). On the association between voluntary disclosure and earnings management. Journal of Accounting Research, 37(1), 57-81. 
Key, K. G. (1997). Political cost incentives for earnings management in the cable television industry. Journal of Accounting and Economics, 23(3), 309-337.

Klein, A. (2002). Audit committee, board of director characteristics, and earnings management. Journal of Accounting and Economics, 33(3), $375-400$.

Kothari, S. P. (2001). Capital markets research in accounting. Journal of Accounting and Economics, 31(1-3), 105-231.

Ljungqvist, A., Marston, F., Starks, L. T., Wei, K. D., Yan, H. (2007). Conflicts of interest in sell-side research and the moderating role of institutional investors. Journal of Financial Economics, 85(2), 420-456.

Matsunaga, S. R., Park, C. W. (2001). The effect of missing a quarterly earnings benchmark on the CEO's annual bonus. Accounting Review, 76(3), 313-332.

Mergenthaler, R. D., Rajgopal, S., Srinivasan, S. (2012). CEO and CFO career penalties to missing quarterly earnings forecasts. working Paper, Harvard Business School.

Mikhail, M. B., Walther, B. R., Willis, R. H. (1997). Do security analysts improve their performance with experience? Journal of Accounting Research, 35, 131-157.

Mikhail, M., Walther, B., Willis, R. (2003). The effect of experience on security analyst underreaction. Journal of Accounting Economics, 35(1), 101-116.

Perry, S. E., Williams, T. H. (1994). Earnings management preceding management buyout offers. Journal of Accounting and Economics, 18(2), 157-179.

Plumlee, M. (2003). The effect of information complexity on analysts' use of that information. The Accounting Review, 78(1), $275-296$.

Rangan, S. (1998). Earnings management and the performance of seasoned equity offerings. Journal of Financial Economics, $50(1), 101-122$.

Roychowdhury, S. (2006). Earnings management through real activities manipulation. Journal of Accounting and Economics, 42(3), 335-370.

Schipper, K. (1989). Commentary on earnings management. Accounting Horizon, 3(4), 91-102.

Shivakumar, L. (2000). Do firms mislead investors by overstating earnings before seasoned equity offerings? Journal of Accounting and Economics, 29(3), 339-371.

Siegel, P., Lessard, J., Karim, K. (2011). Analyst forecast accuracy and firm growth. Advances in Quantitative Analysis of Finance and Accounting, 9, 1-31.

Teoh, S. H., Welch, I., Wong, T. J. (1998a). Earnings management and the long-run market performance of initial public offerings. The Journal of Finance, 53(6), 1935-1974.

Teoh, S. H., Welch, I., Wong, T. J. (1998b). Earnings management and the underperformance of seasoned public offerings. Journal of Financial Economics, 50(1), 63-99.

Thomas, J. K., Zhang, H. (2002). Inventory changes and future returns. Review of Accounting Studies, 7(2-3), $163-187$.

Warfield, T. D., Wild, J. J., Wild, K. L. (1995). Managerial ownership accounting choices, and informativeness of earnings .Journal of Accounting and Economics, 20(1), 61-91.

Watts, R. L., Zimmerman, J. (1986). Positive Accounting Theory, Englewood Cliffs, Prentice-Hall, New Jersey.

Xie, B., Davidson III, W.N., DaDalt, P. J. (2003). Earnings management and corporate governance: the roles of the board and the audit committee. Journal of Corporate Finance, 9(3), 295-316.

Zang, A. Y. (2012). Evidence on the trade-off between real activities manipulation and accrual-based earnings management. Accounting Review, $87(2), 675-703$. 